\title{
SPTLC1 wt Allele
}

National Cancer Institute

\section{Source}

National Cancer Institute. SPTLC1 wt Allele. NCI Thesaurus. Code C127889.

Human SPTLC1 wild-type allele is located in the vicinity of 9q22.2 and is approximately 84 $\mathrm{kb}$ in length. This allele, which encodes serine palmitoyltransferase 1 protein, is involved in the metabolism of lipids. Mutation of the gene is associated with hereditary sensory neuropathy type IA. 